\title{
Strategi Pemasaran Produk Tabungan Ib Hijrah Rencana Pada Bank Muamamalat Cabang Manado
}

\author{
Afnan I. Abbas \\ Tinneke M. Tumbel \\ J. A. F. Kalangi \\ Jurusan Ilmu Administrasi, Program Studi Administrasi Bisnis \\ Fakultas Ilmu Sosial dan Politik, Universitas Sam Ratulangi \\ afnanihsanullah06@gmail.com
}

\begin{abstract}
This study aims to determine the marketing strategy and analyze the strengths, weaknesses, opportunities and threats of the marketing of ibrahim savings products planned by the Bank Muamalat Manado Branch. This research is a descriptive qualitative study with data collection using data using interview and literature studies, while secondary data and primary data from Bank Muamalat employees in Manado Branch. The strategy used by Bank Muamalat Indonesia Branch Manado is to analyze internal and external factors. From the results of this study it can be concluded that the marketing strategy applied is that there are two major factors, namely internal factors and external factors, internal factors using the method of segmentation, targeting, positioning and marketing mix. As well as analyzing external environmental factors such as political, economic, social and technological factors also analyze industrial environments such as newcomers, competition in industry, threats from substitute products and buyers' bargaining power.
\end{abstract}

\section{Keywords: Strategy, Marketing, Product}

\section{Pendahuluan}

Pada era globalisasi, produk atau jasa yang bersaing dalam satu pasar semakin beragam yang mengakibatkan keterbukaan pasar, sehingga persaingan antar produsen untuk mememnuhi keinginan dan kebutuhan dari konsumen dapat dipenuhi, serta kepuasan yang didapatkan oleh konsumen secara maksmimal. Tujuan dari bisnis adalah menciptakan rasa puas pada konsumen. Maka dari itu sudah menjadi kewajiban bagi seluruh perusahaan untuk mempunyai strategi dalam menghadapi persaingan yang terjadi.
Strategi pemasaran sebuah perusahaan memiliki peran yang sangat penting untuk dapat mencapai keberhasilan usaha, oleh karena itu bagian pemasaran menjadi bagian yang berperan sangat penting dalam mewujudkan rencana usaha. Strategi pemasaran sudah seharusnya dapat memberikan sebuah gambaran jelas dan terarah tentang proses pemasaran dan tujuan yang akan dicapai perusahaan dalam memaksimalkan segala kesempatan atau peluang dan menghindari ancaman.

Produk sebagai sesuatu yang dapat ditawarkan untuk memenuhi kebutuhan 
atau keinginan, pentingnya suatu produk fisik bukan terletak pada kepemilikannya, tetapi pada jasa yang dapat diberikannya (Kotler, 2016: 9).

Salah satu produk yang diciptakan oleh Bank Muamalat Indonesia adalah produk tabungan iB Hijrah Rencana, tabungan dengan setoran rutin setiap bulan yang tidak dapat di ambil (sewaktu-waktu) untuk mewujudkan keinginan nasabah untuk melanjutkan pendidikan, me-langsungkan pernikahan, beribadah haji / berwisata, membayar uang muka rumah, membeli kendaraan, berkurban saat Idul Adha, mempersiapkan pension/hari tua. Dengan diciptakannya produk tabungan iB Hijrah Rencana, diharapkan menjadi solusi perencanaan keuangan syariah bagi mereka yang hendak menabung namun juga hendak memenuhi kebutuhan atau perencanaan dimasa yang akan datang. Sehingga nasabah tidak perlu menabung untuk masa depan nya dan untuk perlindungan asuransi jiwanya ditempat berbeda. Dengan adanaya kegiatan sosialisasi dan promosi yang sesuai diharapkan agar masyarakat mengetahui seluk beluk tentang produk tabungan iB Hijrah Rencana ini. Karena Banyaknya persaingan antar bank saat ini, maka Bank Muamalat Cab. Manado yang memiliki produk tabungan iB Hijrah Rencana dituntut untuk melakukan proses pemasaran yang dapat menarik minat masyarakat atau calon nasabah menjadi nasabah Bank Muamalat. Pemasaran yang diterapkan haruslah menerpa suatu strategi yang tepat dalam rangka menarik minat masyarakat untuk menjadi nasabah dan mempertahankan nasabah yang sudah ada.

Dari definisi di atas peneliti menyimpulkan bahwa penasaran adalah kegiatan untuk memenuhi kebutuhan dan keinginan konsumen (pasar) dalam rangka memperoleh keuntungan.

Tujuan pokok strategi segmentasi, targeting, dan positioning adalah memposisikan suatu merek dalam benak konsumen sedemikian rupa sehingga merek tersebut memiliki keunggulan kom-petitif jika produk tersebut menawarkan atributatribut determinan (yang dinilai penting dan untik oleh para pelanggan). Untuk itu, langkah pertama yang harus dilakukan adalah melakukan segmentasi pasar secara cermat. Secara garis besar segmentasi bisa diartikan sebagai proses mengelompokkan pasar keseluruhan yang heterogen menjadi kelompok-kelompok atau segmen-segmen yang memiliki kesamaan dalam hal kebutuhan, keinginan, perilaku dan atau respom terhadap program pemasaran spesifik. Segmentasi pasar merupakan konsep pokok mendasari strategi pemasaran perusahaan dan peng-alokasian sumber daya yang harus dilakukan dalam rangka meng-implementasikan program pemasaran. Segmen pasar terdiri dari sekelompok pelanggan yang memiliki kesamaan dalam hal tuntunan kepuasan terhadap suatu produk. Jika kita mendefisikan segmen pasar atas dasar manfaat dan atau solusi ataas masalah.

Tahap kedua, targeting mengevaluasi daya tarik masing-masing segmen menggunakan variabel-variabel yang bisa 
kuantifikasikan kemungkinan permintaan dari setiap segmen misalnya (tingkat, pertumbuhan segmen bersangkutan), biaya melayani setiap segmen (misalnya biaya distribusi), biaya memmproduksi dan jasa yang diinginkan pelanggan (misalnya biaya produksi dan difrensiasi produk) dan kesesuaian antara kompetensi inti perusahaan dan peluang sasaran segmen. Memilih salah satu atau lebih segmen saasran yang ingin dilayani berdasarkan potensi laba segmen tersebut dan kesesuaiannya dengan strategi korporat perusahaan.

Tahap ketiga, positioning setelah perusahaan memutuskan segmen pasar yang akan dimasuki selanjutnya harus diputuskan posisi mana yang ingin ditempati dalam segmen tersebut. Positioning adalah cara produk, atau merek produk dipresepsikan secara relatif dibandingkan dengan para pesaing oleh pelanggan saat ini maupun calon pelanggan. (Tjiptono \& Chandra, 2012).

\section{Metode Penelitian}

Pendekatan penelitian ini menggunakan pendekatan kualitatif deskriptif. Tujuan dari pendekatan desktiptif kualitatif yaitu untuk menggambarkan, meringkaskan berbagai kondisi, berbagai situasi, atau berbagai fenomena realitas sosial yang ada di masyarakat yang menjadi objek penelitian dan berupaya menarik realitas itu kepermukaan sebagai suatu ciri, karakter, sifat, model, tanda atau gambaran tentang kondisi, situasi ataupun fenomena tertentu (Moleong, 2017).
Sumber data merupakan hal yang paling utama dalam sebuah penelitian karena hal tersebut merupakan cara agar dapat menentukan kekayaan data yang diperoleh. Adapun sumber daa yang digunakan dalam penelitian ini adalah data promer dan data sekunder

Data primer adalah data yang diperoleh langsung dari sumbernya atau sumber pertama dimana sebuah data dihasilkan. dalam hal ini data yang diperoleh merupakan hasil panduan wawancara (interview) mengenai strategi pemasaran produk tabungan ib hijrah rencana pada Bank Muamalat cabang Manado.

Data sekunder yaitu data yang diperoleh secara tidak langsung atau data yang telah tersedia dari hasil pengumpulan data instansi terkait dengan objek penelitian. Dalam hal ini adalah data yang diperlukan dalam rangka untuk melengkapi informasi yang diperoleh dari data primer. Data sekunder dalam penelitian ini dapat diperoleh dari dokumen-dokumen yang berkaitan dengan penelitian ini serta data yang diambik dari Bank Muamalat cabang Manado.

Penelitian ini merupakan penelitian kualitatif, sehingga teknik analisis data yang digunakan ialah analisis kualitatif. Adapun model analisis data yang digunakan ialah model analisis interaktif Miles \& Huberman, (Sugiyono, 2017).

\section{Hasil Penelitian}

Hasil penelitian yang didapatkan yaitu strategi pemasaran yang digunakan Bank Muamalat cabang Manado dalam 
memasarkan produk Tabungan iB Hijrah

Rencana yaitu dengan pendekatan segmentation, targeting, positioning, dan marketing mix.

Segmentasi, Tabungan iB Hijrah Rencana merupakan salah satu produk unggulan Bank Muamalat Indonesia dengan segmentasi demografis dan tingkah laku. Secara umum segmentasi demografis Bank Muamalat Indonesia Cabang Manado untuk seluruh produk tabungan, segmen pasarnya yaitu terhadap se-kelompok orang yang paham dan mengerti hukum Islam yang diajarkan di agamanya yang menjelaskan suatu riba itu me-rupakan haram. Secara khusus untuk tabungan iB Hijrah Rencana dalam segmentasi demografi yaitu mereka di usia 17-30 tahun yang akan mempersiapkan untuk melanjutkan studi, biaya pernikahan hingga perencanaan di masa tua. Segmen tingkah laku ialah segmen terhadap sekelompok orang yang memiliki pengetahuan terhadap bank syariah yang hanya memikirkan karena keuntungan atau manfaat dari produk bank syariah.

Target pasar pada produk Tabungan iB Hijrah Rencana ini dibagi menjadi dua jenis, yaitu pasar spiritual dan rasional. Pasar spiritual adalah segmen pasar khususnya penduduk muslim yang benarbenar mengerti hukum syariah yang merupakan ajaran agamanya. Pasar rasional adalah sekelompok orang yang bukan muslim, namun memiliki ke-tertarikan dengam produk Tabungan iB Hijrah Rencana semata-mata karena manfaat dan keuntungan yang ditawarkan.
Secara umum Bank Muamalat Indonesia mengambil posisi dengan tagline "\#AyoHijrah" hal ini bertujuan untuk mengajak para nasabah agar mulai untuk berpindah atau dalam bahasa Arab di sebut Hijrah ke bank yang berbasis syariah terlebih khusus untuk berpindah ke Bank Muamalat Indonesia.

Secara khusus untuk produk Tabungan iB Hijrah Rencana, PT. Bank Muamalat Indonesia, Tbk Cabang Manado meyakini untuk menjadi "Solusi Perencanaan Keuangan yang tepat yang sesuai prinsip syariah" untuk perbankan syariah di kota Manado. Untuk mencapai posisi tersebut tentu harus dilakukan beberapa hal yakni penetrasi pasar dan melakukan sosialisasi yang tepat kepada masyarakat kota Manado. Sesuai dengan misi Bank Muamalat Indonesia yaitu menjadi "Role Model Lembaga Keuangan Syariah dunia dengan penekanan pada semangat innvestasi yang inovatif untuk memaksimumkan nilai bagi stakeholder merupakan bank yang fokus dan berkomitmen terhadap prinsip syariah.

Tabungan iB Hijrah Rencana, adalah salah satu produk tabungan ib hijrah yang di tawarkan oleh bank muamalat. Produk ini dengan citra sebagai "Solusi Perencanaan Keuangan Syariah" yang menawarkan berbagai macam kegunaan atau manfaat kepada nasabah seperti, perencanaan pendidikan, pernikahan, perjalanan ibadah atau wisata, uang muka rumah, berkurban saat idul adha, persiapan hari tua, serta rencana atau impian lainnya. 
Dalam strategi produknya, Bank Muamalat Indonesia menawarkan berbagai manfaat produk tabungan dari iB Hijrah Rencana, yang menjadi keunggulan dibanding produk sejenis yang ditawarkan Bank syariah lainnya. Adapun kunggulan yang ditawarkan mulai dari perlindungan asuransi gratis dan otomatis, fleksibel, rasa nyaman, jaminan tercapainya target dana.

Penentuan harga sebagai strategi pemasaran produk tabungan iB hijrah rencana yaitu dengan menawarkan minimum setoran mulai dari Rp.100.000 dan tidak dikenakan biaya administrasi.

Strategi tempat yang digunakan Bank Muamalat Indonesia cabang anado dengan menempatkan lokasi yang sangat strategi dijalan utama manado, dekat dengan pusat perbelanjaan serta perusahaan-perusahaan agar memudahkan nasabah.

Kegiatan promosi yang dilakukan mulai dari pendekatan Cross Selling oleh Customer Service, Brosur ikaln, website, sosial mediadan direct selling atau penjualan secara langsung.

Kekuatan yang dimiliki Bank Muamlat Indonesia cabang Manado adalah pelopor bank syariah di Indonesia, citra perusahaan baik, produk tabungan ib hijrah memiliki fitur menarik, pemegang saham BMI merupakan terdiri dari pemilik modal yang kuat dan memiliki sumber daya manusia yang berkwalitas.

Kelemahan yang dimiliki BMI cabang Manado yakni tidak adanya kantor cabang pembantu, fitur mobile banking yang kurang diperbaharui, jumlah ATM masih kuranh serta presentasi bagi hasil yang rendah dengan nisbah atau bagi hasil $30 \%$.

Peluang yang dimiliki BMI yakni masyarakat mulai tertarik terhadap sistem perbankan syariah, masih luasnya pangsa pasar bank syariah secara nasioanl, nasabah pada spiritual market.

Ancaman merupakan faktor yang merugikan perusahaan sehingga akan mengganggu keberlangsungan seuatu kegiatan. Adapun ancaman bank muamalat , minimnya sumber daya manusia yang kompeten dan menguasai produk-produk perbankan syariah, semakin inovatif fitur produk bank pesaing yang dilengkapi dengan teknologi canggih, semakin banyak bank umum syariah dan unit usaha syaraih yang tumbuh di Indonesia. Serta semakin gencarnya promosi bank syariah kompetitior.

\section{Kesimpulan}

Strategi pemasaran yang diterapkan Bank Muamalat Indonesia dalam memasarkan produk Tabungan iB Hijrah Rencana adalah melakukan pendekatan Segmentation Targeting Positioning (STP) dan Marketing Mix atau bauran pemasaran.

Kekuatan yang dimiliki sebagai pelopor bank syariah di Indonesia, citra perusahaan baik produk tabungan dengan memiliki banyak fitur, serta pemagang saham yang kuat. Kelemahan, tidak adanya kantor cabang, mobile banking yang kurang diperbarui, kurangnya jumlah ATM dan pembagian bagihasil yg rencah. Peluang, masyarakat mulai tertarik dengan sistem perbankan syariah, masih luasnya pangsa 
Moleong, Lexy 2017. Metodologi pasar bank syariah, dan nasabah pada spiritual market. Ancaman produk pesaing semakin inovatid minimnya SDM yang berkompeten, semakin gencarnya promo bank syariah kompetitior dan semakin Penelitian Kualitatif. Bandung: PT Remaja Rosdakarya.

banyak Bank Umum Syariah dan Unit Usaha Syariah yang tumbuh di Indonesia.

\section{Saran}

Hendaknya pihak Bank Muamalat Indonesia Cabang Manado meningkatkan kualitas pelayanan secara maksimal dan mensosialisasikan dan menjelaskan secara jelas produk yang ditawarkan.

Bank Muamalat Indonesia cabang Manado dapat menambah fitur produk dan fasilitas khususnya mobile banking agar sesuai kebutuhan nasabah.

Pihak Bank Muamalat Inondesia cabang Manado juga harus melakukan perundingan ulang terkait penawaran nisbah atau bagi hasil yang cukup rencah hal ini mepengaruhi kepusan nasabah dalam melakukan pembelian produk.

\section{DAFTAR PUSTAKA}

Assauri, Sofjan, 2013. Manajemen Pemasaran, Jakarta: Raja Grafindo, Persada

Chandra G, Tjiptono F. 2012. Pemasaran Strategik. Yogyakarta. Andi Offset

Kasmir, 2014. Dasar-Dasar Perbankan. Jakarta: PT. Grafindo Persda

Kotler Philip, dan Keller Kevin Lane, 2016. Manajemen Pemasaran Jakarta: Salemba empat

Sugiyono, 2017. Metodologi Penelitian Bisnis. Bandung : Alfabeta 